\title{
Eylem ve Anlamın Postyapısalcı Görünümü
}

\author{
Poststructuralist View Of Action And Meaning
}

\section{Ömer Say}

\section{Öz}

Nietzsche ve çağdaş postyapısalcı düşünürler, tüm Batı düşüncesinin idealizmin ve diyalektik düşüncenin etkisi altında olduğunu öne sürmektedirler. Çağdaş postyapısalcı düşünürlerin eserlerinde Sokrates ve Platon'un ortaya koyduğu yaklaşımlar sonucunda diyalektik düşüncenin tarihte egemen olduğu iddia edilmektedir. Nietzsche ise diyalektik düşüncenin başlangıcını Sokrates öncesi dönemden başlatır ve diyalektik düşünceyi köle ahlakına bağlar. Ancak hem Nietzsche hem de çağdaş postyapısalcılar düşünce tarihine yönelttikleri eleştirilerinde farklı disiplinleri incelemeye tabi tutarlar. Böylece bu düşünürler bilginin önce egemen bakış açıları aracılığıyla toplumsal bir süreç olarak inşa edildiği ve sabitlenerek belirli çıkar gruplarının hizmetinde devam ettiğini varsayarak bilgiye erişimde alışılagelmiş egemenlik kurucu bakış açısı yerine kendi yaklaşımlarını önerirler. Bu çalışmada, Nietzcshe, Deleuze ve Guattari, Derrida ve Foucault'nun düşünceleri eleştirel bir gözle inceleme konusu yapılmıştır.

Anahtar Kelimeler: Nietzcshe, Deleuze ve Guattari, Derrida, Foucault, Postyapisalcılık, Diyalektik.

Prof. Dr., Marmara Üniversitesi, Fen-Edebiyat Fakültesi, Sosyoloji Bölümü Öğretim Üyesi, omer.say.omer@gmail.com

Bu makale iThenticate sistemi tarafından taranmıştır.

Makale Gönderim Tarihi: 9 Kasım 2020 


\begin{abstract}
Nietzshe and contemporary poststructuralist thinkers argue that all Western thought is under the influence of idealism and dialectical thought. In the works of contemporary poststructuralist thinkers it is claimed that dialectical thought became dominant in history as a result of the approaches put forward by Socrates and Plato. Nietzsche originates the beginning ofdialectical thought in the pre-Socratic period and link dialectical thought to slave morality. However, both Nietzsche and contemporary poststructuralists reanalyze the history of thought in their works. These thinkers assume that knowledge has been first constructed as a social process through dominant perspectives and continues to be fixed and served to certain interest groups. Instead of conventional viewes in accessing knowledge, they propose their own methods. In this study, the thoughts of Nietzcshe, Deleuze and Guattari, Derrida and Foucault are analyzed critically.
\end{abstract}

Keywords: Nietzcshe, Deleuze and Guattari, Derrida, Foucault, Poststructuralism, Dialectics. 


\section{Giriş}

Varlık yerine eylemin düşüncenin başlangıç noktası olarak ele alınması sabit bir doğrunun ve iyinin varlığından söz etmenin de imkansızlığını gerektirmektedir. Hatta sadece felsefi açıdan değil toplumsal ilişkiler açısından da sabit bir değer ya da kültürün varlığı kabul edilemez hale gelir. Zira bu düşünce içinde her şey, geçici bir konumda ve dolayısıyla süreksizlik içererek oluşmaktadır. Böylece değişim, oluşan şeyin anlamını belirlemekte ve onu da değişken hale getirmektedir. Artık eylem ve değişimin ne başlangıcının ne de sonunun olduğu kabul edilir. Değişimin mutlaklığının bu ifadesi aynı zamanda 'neden' sorusunu da ortadan kaldırır. Hiçbir şey sabit olarak var olmadığına göre neden ya da etkinin varlığından söz etmek ancak bir kabullenme ve ona itaat olarak anlamlandırılacaktır.

Bu düşünce biçiminin sosyolojik teoriler ve özellikle sosyal teori üzerine etkisi, insan ilişkilerinde her şeyin yüzer gezer olduğu, bunun dışındaki tüm kabul edilen düşüncelerin yalnızca tahakküm aracı olarak geliştirildiği iddiasına dönüşmektedir. Gerçekten de postyapisalcı düşünürlerin Nietzsche'den ilham alarak geliştirdikleri teoriler insan ilişkilerini bir varlığın ya da yapının etrafında açıklayan klasik yaklaşımları tahakkümcü bir bakış açısının ürünü olarak değerlendirmektedir. Bu çalışma özetle postyapısalcı yaklaşımın önde gelen bazı düşünürleri ile Nietzsche arasındaki ilginin ve Nietzsche üzerinden de Herakleitos'a uzanan bir geleneğin izini sürerek tartışma konusu yapmaktadır. Kısaca geleneğe karşı çıkan ancak kendisi de bir başka gelenek içinde süregelen bir düşünce biçiminin temellerine odaklanmaktadır.

\section{Nietzsche ve Diyalektiğin Reddi}

Putların Alacakaranlığı adlı eserinde Nietzsche, Sokrates öncesi Antik Yunan düşüncesiyle nizam verilen toplumda diyalektiğin dışlanmış olduğunu söyler. Ona göre diyalektiğin dışlandığı bu nizam soylu bir beğeninin ifadesi olmakla birlikte Sokrates düşüncesi tarafından yenilgiye uğratılmış ve böylece diyalektik düşünmenin egemenliği ile en düşük kesim tepeye çıkmıştır (Nietzsche, 2004: 23). 
Nietzsche'nin sert eleştiriye tabi tuttuğu diyalektik düşünme biçimi en genel haliyle karşıtların varlığı içinde senteze ve böylece bir sonuca ulaşmayı gaye edinmektedir. Düşüncenin bizzat bir hedefe doğru yönelmesi, hedefin aynı zamanda düşünceye karşı egemen konumda olmasını gerektiren bir gerçekliği zorunlu kılmaktadır. Bu durum Nietzsche'nin kabul edemeyeceği bir yaklaşım biçimidir. Çünkü ona göre kişinin kendisi olma dişında bir gerçeklik görüp ona yönelmesi ancak köleliğin mevcudiyeti ile açıklanabilir. Zira Nietzsche'nin düşüncesinde köle ahlakı harekete geçmek için karşıta veya dişsal uyaranlara ihtiyaç duyar. Onun eylemi aslen bir tepkidir (Nietzsche, 2008:20).

Dışsal bir gerçekliğin varlığı bizzat idealizmin düşünce biçimi ile barışık bir görüntüyü gerekli kılar. İdealizmde hedef ve amaç da yerli yerine oturmaktadır. Çünkü İdealizmin öncüsü olarak görülen Platon felsefesinde düşünce, aşkın bir yapı olan idealarla kontrol edilir ve hakikate yönlendirilir (K1lıç, 2013: 183). Kavramlar, ya da kavramlarla ifade edilen varlık alemi idealarla bütünlük içinde ise hedef ve amaç sağlanmış olmaktadır.

Oysa Nietzsche'nin yöntem olarak öne sürdüğü geneology, Foucalt'nun, belirttiği gibi, ideal anlamlandırmaların metahistorik yayılımını kabul etmez (Foucault, 1996: 140). Zira ideal anlamlandırma eylemi kendine bir hedef koyarak maddi oluşu ikincil konumda tutan bir amaca doğru yön almayı ifade etmektedirler.

\section{Nietzsche'nin Hıncı: Anlamın Varlık ve Eylem Üzere Kurulma- sindaki Fark}

İdeal anlamlandırmanın bizzat temelinde yer alan Platon'un felsefesinde varlık ve düşünme temsiliyet alanı içinde kurulmaktadır. Temsil, mutlak gerçeklik olan ideaların kopyalarından yani nitelik ve materyal objelerden oluşmaktadır (Kılıç, 2013: 36). Bu haliyle de Platon felsefesinde temelde yer alan gerçeklik, varlık ve varlığın kaynağı olarak görülmektedir. Bu yüzden varlığın anlamlandırılması gerçekliğin ve hakikatin anlamının yakalanması üzerine kuruludur. Oysa Nietzsche, felsefi düşünce içinde Antik Yunan filozoflarından Herakleitos gibi farklı bir temeli referans almaktadır. Herakleitos'a göre tarihin seyrinde akışkanlık bulun- 
maktadır (Russel, 1983: 47). Her şeyin akışkan olduğunu söyleyen Herakleitos, varlığın sabit oluştan ziyade bir akışla gerçekleştiğini belirtmektedir. Herakleitos'un açılamaları sadece Nietzsche ile değil aynı zamanda çağdaş postyapısalcı düşünce ile de paralellik göstermektedir.

Herakleitos'un felsefesinin temelinde iki düşünsel yaklaşımı vardır: birine göre varlık yoktur, her şey bir oluştur. Diğerine göre de varlık bir oluşun varlığıdır. Bu iki düşünme şekli birbirinden ayrılamaz. Dahası, Herakleitos'a göre oluşun ötesinde bir varlık olmadığından çokluğun ötesinde de hiçbir şey yoktur (Deleuze, 2002: 23). Zira oluş sürekli olarak bir değişimi ve akışı gerektirdiği için hiçbir şey sabit ve tek başına olarak mevcudiyet göstermemektedir.

\section{Nietzsche ve Eylem}

Herakleitos'un bu yaklaşımı Nietzsche' nin de düşüncesinde başlangıç noktası olarak kendini gösterir. Nietzsche'ye göre form akışkandır, 'anlam' ise daha da fazla akışkandır. Hiçbir tek organizmanın içinde de farklı değildir. Bütündeki her gözle görülür derecede büyüme sonucunda, her bir organın anlamı da değişir. Oysa, Herakleitos'un öne sürdüğü haliyle, her şeyin bir oluş halinde gerçekleştiği akışkanlık fikri Sokrates ve Platon düşüncesi ile terkedildiğinde artık oluş ve varlık tarih içinde üstün bir güç tarafından yeniden yorumlanmış ve dönüştürülerek yeni bir amaca yönlendirilmiştir. Var olan herhangi bir şey sürekli olarak kendinden daha üstün bir güç tarafından yorumlandığı için dünyada vuku bulan her şey, bir boyun eğdirme ve hükmetme ile açılanmıştır. Boyun eğdirme ve hükmetme de zaten önceki anlamları ve amacı zorunlu olarak bozacak bir süreçte yeniden yorumlama ve düzenlemeden ibarettir (Nietzsche, 2008: 51). Nietzsche için böyle bir üstünlük kurulabilen gerçeklik yoktur. Zira onun varlık yerine harekete yönelmiş olması idealizmde görülen mevcut dünyaya ilişkin bir alt katman ayrımını reddetmesi anlamına gelmektedir. Bu yüzden o, açıkça ama böyle bir alt katman yoktur; eylemin arkasında bir 'varlık' yok; 'eylemci', eyleme sonraki bir düşünce olarak icat edilmiştir. Eylem her şeydir diyerek karşı çıkmaktadır (Nietzsche, 2008: 26). 
Deleuze'e göre Nietzsche' nin öne sürdüğü “Bu yeni söylem artık biçimin söylemi değildir, ama biçimsizliğin söylemi de değildir: o daha ziyade saf biçim dışıdır... Felsefeyi yenilemesi gereken ve anlamı nihayet yüklem olarak, özellik olarak değil olay olarak ele alan tuhaf bir söylem" (Deleuze 2015: 129-130). Aslında Deleuze, her ne kadar tuhaf olarak adlandırsa da bu tuhaflığı olumsuz anlamda değerlendirmez. Tuhaflık alışık olunmayan bir düşünce olarak görülmesindendir. Çünkü o da Nietzshe'nin izini sürmektedir.

\section{Deleuze ve Oluş}

Deleuze de sabit varlık yerine olayı ve oluşu düşüncesinin temeline oturtmaktadır. Ancak o, Herakleitos ve Nietzsche'deki oluş fikrine Stoa felsefesinin materyalist yorumunu da ekleyerek bakış açısını zenginleştirmek ister. Deleuze'e göre "(Stoacılar) onlardan önce kimsenin yapmadığı şeyi yapıp iki olma düzlemini baştan sona (birbirinden ayırırlar): bir yanda derin ve gerçek varlık, kuvvet vardır, diğer yanda ise varlığın yüzeyinde ortaya çıkan ve sonsuz bir cisimsiz olmalar çokluğu meydana getiren olgular düzlemi" (Deleuze, 2015: 21).

Deleuze'un belirttiği haliyle Stoacılar, cisimlerin derinliğinde karışımların olduğunu öne sürerek bu ayrımı ortaya koymaktadırlar. Stoacılara göre bir cisim diğerine nüfuz etmekte ve parçalarının tamamında onunla birlikte var olmaktadır. Denizdeki şarap damlası ya da demirdeki ateş buna örnek gösterilmektedir. Genel olarak karışımlar niceliksel ve niteliksel şey durumlarını, sözgelimi demirin kızdırılmışlığını ya da bir ağacın yeşilliği gibi bir bütünün boyutlarını belirlemektedirler. Bu haliyle, Deleuze'e göre, Stoacılar cisimlerin birbirleri ile karışımını da cisim olarak ele almaktadırlar. Karışımlar niceliksel ve niteliksel şey durumlarını belirlerler. Fakat eyleme dökülme anı sadece bir eylem olarak ele alınmaktadır. Bu bakımdan eylemin, yani oluşun kendisi cisim değil, tam olarak 'cisimsizdir. Çünkü eylem ile yani, 'büyümek', 'küçülmek', 'kızdırılmak', 'kesmek', 'kesilmek' vb. derken kastedilen cisimlerin derinlerindeki karışımlar değil, bu karışımların neticesi olan, yüzeydeki cisimsiz olaylardır (Deleuze, 2015: 20-22). 
Deleuze'e göre Stoacıların ortaya koyduğu bu ikilik felsefede bir altüst oluşa yol açmıştır. Zira Aristoteles düşüncesinde görülen şekliyle varlığa bağlı olarak yapılan açıklamalar terkedilmiş ve en yüksek terim varlık değil herhangi bir şey olmuştur (Deleuze, 2015: 23). Bu durumda da anlam ve varlık arasındaki ilişkiden ziyade anlam ve eylem arasındaki ilişki önem taşımaktadır.

Bu yaklaşımın Deleuze felsefesi için önemi büyük olmuştur. Zira ona göre de artık anlam bir eylem, yani olaydır. Olay da anlamın ta kendisidir (Deleuze, 2015: 39). Deleuze'ün ifadesiyle artık "söz konusu olan hep İdeaları yerinden etmek ve cisimsiz olanın yukarıda değil yüzeyde olduğunu, en yüksek neden değil en mükemmel yüzey etkisi olduğunu, Öz değil olay olduğunu göstermektir" (Deleuze, 2015: 151). İdealara ilişkin bu söylem aynı zamanda düşünce tarihi içindeki bilginin kökeni sorusunu yeniden sorgulamak demektir. Ancak bu sorgulayışta doğrudan empirizmden bir beslenme görülmektedir. Böylece cisimsizlik, soyut olan idealar aleminden maddi alandaki oluş ve eylem düzeyine çekilmektedir.

\section{Deleuze ve Zaman}

Deleuze felsefesi için Stoacıların önemi bununla sınırlı kalmaz. Onların zaman kavramına yaklaşımları da önemlidir. Stoacılara göre "cisimlerin ve şey durumlarının tek zamanı şimdidir" (Deleuze, 2015: 20). Dahası onlar için "zamanda sadece şimdi var olur ve geçmişle geleceği birleştirir, kendinde eritir, ama aynı zamanda sadece geçmiş ve gelecek içten-içe-olur ve şimdiyi sonsuzca böler" (Deleuze: 2015: 21). Her şeyden önce, şimdiyi sonsuza bölüş alışılagelmiş olan ilerlemeci ya da ilerleyen zaman anlayışından farklı bir düşünme biçimini ortaya çıkarmaktadır. Zira bu durumda herhangi bir şekilde olan şey ya da oluş artık sadece şimdinin içinde salınabileceği için bir teleolojiyi de imkansız kılmaktadır. Artık onun bir amaca doğru ilerleyişi söz konusu olamaz. Böylece cisim ve şeyler mevcut zaman içinde kendi başlarına yer almaktadır. Sonuçta da anlamın ancak belli bağlam ve koşullar altında değişmesine ve çoğalmasına bir zemin hazırlanmaktadır. 


\section{Deleuze ve Guattari'de Süreksizlik}

Stoacıların bu bakışı çok açık olarak Deleuze ve Guattari'nin şizoanalitik düşünme biçimiyle oldukça uyumludur. Zira Deleuze ve Guattari'ye göre evrensel tarih zorunluluklar değil tesadüfler tarihidir. O sürekliğin değil kesilmelerin ve sınırların tarihidir (Deleuze-Guattari, 2014a: 206). Tarihin akışı bir toplum türünden bir diğerine geçiş ya da bir ilerleyici gelişme değildir. Tarih daha ziyade tesadüflerin kazaların, rastlantısal karşılaşmaları gibi akışı kapsamaktadır. Bu akış süreklilik ya da ilerleme değil, tersine kopmaların, kesintilerin, dönüşümlerin bulunduğu bir süreksizliktir (Buchanan, 2008: 139). Deleuze ve Guattari'ye göre tarih her zaman, konu göçebeler olduğunda dahi yerleşik bakış açısıyla yazılmıştır (Deleuze-Guattari, 2014b: 24). Göçebelikle kastedilen de yerleşiklerden önce gelme değildir. Göçebelik bir harekettir (Deleuze-Guattari, 2014b: 500).

Deleuze ve Guattari için bir yerde ya da düşüncede kök salma göçebeliğe uygun değildir. Göçebelik için bir kökene ait olmak ya da kök salmaktan farklı olarak daima bir noktadan diğerine bağlantı kurulması gerekmektedir. Böyle kökü olmayan bir oluşumun adı ise rizomdur. Bu yüzden de olması gereken bir yere sabitlenmek değil tam aksine hareketliliktir Mevcut tarih anlayışının yerleşiklik üzerine olması da rizomun değil kök üzerine kurulmasından kaynaklanmaktadır. Çünkü rizom, hareketli olan boyutlardan ve yönlerden oluşmuştur. Ne başlangıcı vardır ne de sonu. Sürekli olarak gelişen ve yayılan bir ortama sahiptir. O öznesi ve nesnesi bulunmayan n boyutlu çokluktur (Deleuze-Guattari, 2014b, 2122). Deleuze ve Guattari'nin n boyutlu çokluğu öne çıarması da zaten idealizmle iç içe geçmiş olan diyalektik düşüncenin uygulanamayacağı bir bakış açısını ortaya koymaktadır. Daima hareket halindeki göçebelik dolayısıyla bir sabit hedefinin olması da imkansız hale gelmektedir. Bu durumda da idealizm ve diyalektik içinde yer alan teleolojinin onların düşünce biçiminde anlamı olmaz. Bu bakış açısından sürekli eylem ve hareket nedeniyle daha ziyade bir empirisizm yorumu çıkmaktadır. 


\section{Derrida ve Mevcudiyet Metafiziği}

Nietzsche' nin düşüncesi ile paralellik gösteren bir başka düşünür Derrida'dır. Derrida'ya göre de varlığın bizzat başlangıç olarak belirlendiği 'anlam, konuşma, mantık, akıl, Tanrı sözü' anlamlarındaki logos, bir metafizik anlayış olarak Batı düşüncesi içinde egemen olmuştur. Dahası Derrida için logos sadece başlangıcı oluşturmaz kendisinden türetilen logocentrism ile aynı zamanda bir merkez fikrini de ortaya koyar (Derrida, 1981: IX). Logocentrism ayrıca varlığın mevcudiyet olarak belirlenmesine de destek olmaktadır (Derrida, 1997: 12).

Derrida'ya göre yapıda bir merkez ya da bir varlık noktasına, sabit bir kökene gönderme yapmak Batı düşünce geleneği kadar eskidir. Bir yapının merkezi, unsurlarının kapsayıcı bir form içinde düzenlenmesini sağlamaktadır. Bu merkeze dayanarak kökeni her zaman yeniden uyanabilen veya amacı daima mevcudiyet biçiminde öngörülebilen bir tarih ortaya çıkmaktadır. Art arda ve düzenlenmiş bir şekilde merkez, farklı formlar veya isimler almaktadır. Metafizik tarihi, tıpkı Batı tarihi gibi, bu metaforların ve mecazların tarihidir. Merkez, kök veya kaynak ile ilgili olarak aşkınlık, bilinç, Tanrı, insan vb. tüm isimlerin her zaman değişmez bir mevcudiyet olarak adlandırılmasıdır (Derrida, 2005: 351353).

\section{Derrida ve Mevcudiyetin Ses Olarak Yapısal Açılımı}

Bu haliyle Derrida' ya göre geleneksel Batı düşüncesinde hakikatin metafiziksel belirlenimi logostan koparılabilir değildir. Logos'un da sesle ana bağlantısı hiçbir şekilde koparılmamıştır. Böylece logosentrizm aynı zamanda fonocentrism olarak da sayılmaktadır (Derrida, 1997: 10-11). Demek oluyor ki Derrida'ya göre sesin merkeze tutulması zaten mevcudiyet metafiziği halinde kabul etmiş olduğu logostan kaynaklanmaktadır. Bu mevcudiyet metafiziği kendi sistemini ortaya koymakta ve artık hiyerarşik bir ilişki dizilimini de sağlamış olmaktadır. Bu aynı zamanda belirleyen ile belirlenen arasındaki bir ilişkinin varlığını da göstermektedir.

Derrida'ya göre logos'un da sesle (phone) ana bağlantısının kabulü nedeniyle Batı düşünce geleneğinde yazı her zaman söz 
karşısında aşağıda ve ikincil konumda kalmıştır. Çünkü bu gelenekte yazı sadece sözü temsil etmektedir. Saussure de yazıda dar ve türevsel bir işlevden daha fazlasını kabul etmez. Türevseldir çünkü ilk gösterenin göstereni olarak kendi kendine mevcut olan sesin ve anlamın dolaysız, doğal ve doğrudan ifadesidir. Zaten Saussure'nin yaklaşımında da yazının yegane gayesi sözü temsil etmektir. Derrida'nın bakışında Saussure'de yazının sözü temsil etmesinin nedeni tıpkı Platon ve Aristoteles'te olduğu gibi sesçil yazı modeli ve kelimelerin dili ile sınırlı olan tanımı sürdürmüş olmasındandır (Derrida, 1997: 30). Derrida, Saussure'ün devraldığ1 metafizik varsayımlara göre önce anlamlar arasında doğal bir bağ olması gerektiğini belirtir. Saussure de bu yüzden anlamdan sese geçen bağ doğal ve tek gerçek bağ olarak görmektedir (Derrida, 1997: 35). Bu haliyle de yazı dilin temsilcisi olarak sesçil olacaktır (Derrida, 1997: 31). Bu bağ, gösterileni (kavram ya da anlam) sesçil gösterene bağlayan ve aynı zamanda yazıyı da söze tabi kılan bir doğal bağ olarak bulunur (Derrida, 1997: 35). Yani okuma ve yazmadan, göstergenin üretimi veya yorumundan ve de metinden de daha önce logosta oluşturulmuş bir gerçeklik veya anlam vardır (Derrida, 1997: 14). Böyle bir gerçeklik ve anlam Derrida için mevcudiyet metafiziğinin kendisidir.

\section{Derrida ve Yapısökümü}

Derrida mevcudiyet metafiziğine ait sistemi Saussure üzerinden göstermeye çalışarak yapısökümünün gerekirliğini ortaya koymaya çalışır. Derrida'ya göre Saussure için dilde sadece farkl1lıklar vardır. Saussure'e göre gösterilen ya da gösteren olarak da ele alınsa bile bir dil, dilsel sistemin öncesinde varlık gösteren fikirlere ya da seslere sahip olamaz. Dildeki kavramsal ve sesçil farklılıklar sistemden kaynaklanarak bulunmaktadır. Buradan çıkardığ1 sonuçla da Derrida, gösterilenin yani kavramın kendi kendine yetmediğini, böyle bir mevcudiyete sahip olmadığını belirtir. Her kavram, sistematik bir farklılık oyunu içinde zorunlu olarak bir diğerine ve diğer kavramlara atfedilen sisteme veya zincire kaydedilmektedir. Bu durumda da bu şekildeki bir oyun-fark (differance), bir kavram değil olsa olsa kavramsallık ihtimalidir 
(Derrida, 1973: 140). Bu haliyle Derrida için gösterilen olarak kavramın kendi kendine yeten bir mevcudiyete sahip olmamasından ve aynı zamanda başka oluşlarla irtibatının zorunlu hale gelmesinden dolayı değişim yani hareket onun düşüncesinin temelinde yer almaktadır. Bu temelin de sürekli değişim içinde olması Differance'ın kavram olmayışını açıklamaktadır. Çünkü kavram sabit anlamı, yani varlığı gerektirecektir.

Derrida'nın belirttiği haliyle differance, farkları ve farklılık etkilerini üreten oyunun hareketidir (Derrida, 1973: 141). Kendi ifadesiyle differance ilk olarak gecikme, tehir, alıkoyma, rezerve etme gibi anlamlar yoluyla erteleme hareketini ifade eder. İkincisi, dildeki sezme/anlama, doğa/kültür, gibi farklılıklar üreten tüm zıt kavramların ortak köküdür. Üçüncüsü, Saussure tarafından oluşturulan dilbilimin ve onun üzerine biçimlenen yapısal bilimlerin farklılaşmasının üretilmesidir (Derrida, 1982: 8-9).

Bununla birlikte Derrida için farklılıkları üreten differance basit ve kendi içinde değiştirilmemiş ve kayıtsız bir mevcudiyet anlamına gelmez. Düşünürün ifadesiyle differance, tamamlanmayan, basit olmayan, farklılığı farklılaştıran kökendir (Derrida, 1973: 141). Ancak differance'ın köken olduğunu söylemek, aynı anda bir mevcut köken mitinin silinmesidir. Bu nedenle köken, kökensizlik olarak kökenin silinmesidir (Derrida, 2005: 255).

Bu silinmenin nedeni ise Derrida'ya göre farklar oyununun, herhangi bir anda veya herhangi bir anlamda, sadece kendisine atıfta bulunarak, kendi içinde ve kendi kendine basit bir unsur olarak varlık bulmayı yasaklamasıdır. Sözlü ya da yazılı söylem sırasına göre, hiçbir unsur, gösterge olarak sadece kendiliğinden mevcut olmayan başka bir unsura atıfta bulunmadan bir işleve sahip olmaz. Bu iç içe geçme, her bir unsurun zincirin diğer unsurlarının içindeki iz temelinde oluşturulmasını sağlar. Hiçbir şey hiçbir zaman sadece mevcut ya da yok değildir. Her yerde sadece izlerin izleri vardır (Derrida 1982: 26). İşte bu durumda da Saussure'ün öne sürmüş olduğu gösterge sistemi bozulmaktadır. Zira anlamın sürekli olarak değişmesi zaten gösteren ve gösterilen ilişkisinden bağımsız bir ilişkiler zincirini işaret etmektedir. 


\section{Derrida ve Arke-yazı}

Differance'ın asıl önemi ise yazı ile ilgili olarak ortaya çıkar. Derrrida differance'ın daha ziyade yeni bir yazı kavramı üretmek olduğunu söyler (Derrida, 1982: 26). Ancak differance'ın ürettiği yazı sözlü iletişimin yazıya dökülmüş halini ifade etmez. Çünkü Derrida için iletişim kurulan yazı kaba anlamıla yazı demektir (Derrida, 1997: 56). Buna karşın Batı düşünce geleneğinin alışılmış mevcudiyet formuna indirgenmesine izin vermeyen yazı ise arke-yazıdır (Derrida, 1997: 57). Arke-yazı sadece grafiksel anlatım biçiminde ve özünde değil, aynı zamanda grafiksel olmayan anlatımlarda da işe yarayacaktır. Arke-yazı, farklılı̆̆ın hareketidir ve indirgenemez. O, dil sisteminin bir parçası da olamaz (Derrida, 1997: 60). Böylece iletişimin aracı olan kaba yazının da arkeyazı'dan çok farklı olduğu ortaya çıkmış olur. Kaba yazı sözün bir türevi olarak düşünülebilse de arke-yazının sözden ve yazıdan ötede olması buna izin vermez. Daha doğrusu mevcut olarak bulunamayacağı için zaten öncesi ve sonrası ortadan kalkmış olacaktır. Bu haliyle de mevcudiyet olarak düşünülemeyecek olan dil Derrida için bir gösterge sistemi olmaktan ziyade harekettir. Dolayısıyla değişimi gösteren bu hareket de Derrida'nın ifadesinde differance'dir.

Derrida'nın Frued'u yeniden yorumlayarak aktardığı haliyle arke-yazı tıpkı rüyalarda olduğu gibi konuşmanın ve kaba yazının ötesindeki bir yazıdır. Kısaca söylenecek olursa Derrida için rüyaların genel yazımı sesçil yazmayı aşmaktadır. Derrida'nın aktardığ1 haliyle Freud'a göre rüya-düşünceleri ve rüya-içeriği bize aynı konunun iki farklı dilde iki versiyonu gibi sunulur. Rüya düşünceleri, onları öğrenir öğrenmez hemen kavranabilir. Fakat rüya içeriği karakterleri ayrı ayrı rüya düşüncelerinin diline aktarılması gereken bir resimyazı (pictographic) senaryoda olduğu gibi ifade edilir. Resimyazı, yazılı bir görüntü değil, figüratif bir senaryodur. Figüratif içerik bu haliyle bir yazı biçimidir, sahne formunda bir gösteren zincirdir (Derrida 2005: 274). Derrida'ya göre Freud burada rüyayı, kelimeleri onlara boyun eğmeden sahneye koyan özgün bir yazı biçimine benzer bir yer değiştirme olarak algılamaktadır ve hiyeroglif, piktografik, unsurlar gibi konuşmaya in- 
dirgenemez bir yazı modeli düşünmektedir (Derrida, 2005: 262). Bu haliyle Derrida'ya göre arke-yazı tıpkı rüyalarda olduğu şekliyle konuşmanın ve iletişimi ifade eden konuşmanın türevi bir yazmanın ötesindeki bir yazıdır. Bu bakımdan da arke-yazı kapalı bir sistem içinde değildir. O sürekli hareketlilik halindedir. Kapalı bir sisteme özgü olmadığ i için mevcudiyet metafiziğindeki gibi ne bir hiyerarşi ne de öncelik ve sonralık ifade eder. Çünkü o salt bir varlık değildir.

\section{Foucault ve Süreksizlik}

Değişimin oluşu konusunda benzer bakış açısını Foucault'da da görürüz. Foucault'ya göre uzun yıllar boyunca tarihçiler siyasi olayların rota ve değişiminin altında dikkatlerini uzun sürelere çevirmeyi tercih etmişlerdir. Bunun gerçekleşmesi için de farklı olaylar arasında bağlantı, süreklilik veya bütünlük, seriler, nedensellikler, hiyerarşi, hakimiyet gibi konular geleneksel analizin eski soruları olmuştur (Foucault, 1972: 3-4).

Foucalt'nun süreklilik ve bütünlük gösteren tarihe karşı çıkmasındaki ana neden tarih ile özne arasındaki ilişkinin yorumundan kaynaklanmaktadır. Foucault, süreklilik gösteren tarihin, öznenin kurucu işlevinin vazgeçilmez bağlantısı olduğunu iddia etmektedir. Ona göre süreklilik gösteren tarih ile özne, kendinden kaçan her şeyin ona geri yüklenebileceğinin garantisine sahip olmakta ve bir birlik oluşturmaya öncelik vermektedir. Tarihsel analizi sürekliliğin söylemi yapmak ve insan bilincini tüm tarihsel gelişim ve eylemin kökeni yapmak aynı düşünce sisteminin iki yüzüdür. Bu sistemde zaman, bütünleştirme açısından tasavvur edilir ve devrimler de hiçbir şekilde bilincin bir anından daha fazlası değildir (Foucault, 1972: 12). Foucalt'nun süreklilik gösteren tarihe ilişkin bu eleştirel yaklaşımının altında süreklilik düşüncesinin doğrudan idealizme ve hatta hem varoluşçuluğa hem de fenomenolojik felsefeye yol açması yer almaktadır. Üstelik tarih ve insan bilinci arasında kurulan bu bağ bizzat Hegel'in tarih bilinci ve hümanizması ile tam olarak barışık bir bakış açısıdır.

Kaldı ki Foucault konuya bu şekilde baktığını açıkça belirtmektedir. Ona göre bu konu 19. yüzyıldan beri farklı şekillerde tüm 
merkezsizleştirmelere karşı konunun egemenliğinin yanında antropoloji ve hümanizmin ikiz figürlerinin koruması için değişmez bir rol oynamıştır (Foucault, 1972: 12). Üstelik Foucault, böyle bir rol oynayışın da zamanını yansıtmayan bir düşünceden ibaret olduğunu belirtmektedir. Çünkü ona göre aynı dönemde düşünce tarihi, bilim tarihi, felsefe tarihi, edebiyat tarihi gibi alanlarda tarih içeren isimlerine rağmen süreklilik düşüncesindeki tarihçinin çalışma ve metotlarından kaçınmıştır. Bu alanlarda tüm dikkatler, dönemler veya yüzyıllar yerine parçalanmalara ve süreksizliklere yönelmiştir (Foucault, 1972: 4), Çünkü Foucault'ya göre artık fikirler, düşünce ve bilimler tarihinde ortaya çıkan etki, bilincin ilerlemesinin, aklın teleolojisinin veya insan düşüncesinin evriminin oluşturduğu uzun seriyi parçalamıştır. Bu nedenle artık düşüncede ve tarihe bakışta bir bütünlük yaratma olasılığına karşı şüphe duyulmuştur. Böylece gelişmeler farklı serilerin doğrusal bir şemaya indirgenmeden ayrışmasına yol açmıştır. Böylece, ulaşılamaz bir kökene kadar izlenen kronoloji yerine, bir bilincin genel modeline indirgenemez türden bazen çok kısa, birbirinden farklı, tarihe özgü tipten ölçekler ortaya çıkmıştır (Foucault, 1972: $8)$.

Bununla birlikte Foucalt'nun yaptığı açıklama, kendi söylem (discourse) açılaması ile çelişki göstermektedir. Zira ona göre tarih farklı söylem sistemlerinin egemenliği altında süregelmiştir. Bu bakış açısı her şeyden önce bir egemen bakış ve söylem bütünlüğü iddiasını taşır (Say, 2010: 157-158). Bu durumda bir söylem bütünlüğü içinde bilime ait yaklaşımlar ile tarihe ilişkin yaklaşımlar arasında bir farklılık olduğunu kabul etmek, söylem (discourse) egemenliğinin olduğuna yönelik iddia ile çelişir. Zira Foucault yukarıda belirtildiği gibi böyle bir farklılığın olduğunu iddia etmiştir. Eğer discourse'un varlığına ilişkin iddiası doğru ise bu durumda tarihçinin çalışmalarının da discourse' un egemenlik sınırlarında kalması gerekir. Yok eğer tarihçi bu sınırlamadan bağımsız ise bu durumda da discourse' dan söz edilemez.

\section{Sonuç ve Tartışma}

Bilginin rasyonel düşünce ve mutlak doğru olarak ortaya konan düşünceden ziyade insan deneyimi ile geliştiğinin öne sürülmesi 
doğası gereği o bilginin belli şartlar ve bağlamlar ile ortaya çıktığını gösterir. Şartların ve bağlamın gerekliliği ise bilginin ya da bilgi yoluyla oluşturulacak sözün ne süreklilik gösterdiği ne de mutlak ya da değişmez şekilde doğruluk taşıdığı anlamına gelir.

Deneyimin bilgide bu kadar öne çıkmasında Locke'un zihnin boş levha olduğunu belirten "tabula rasa" ifadesiyle öne sürdüğü görüş etkili olsa da Hume, bu konuda daha da ileri giderek deneyim ve nedensellik arasındaki ilişkiyi yeniden yorumlamıştır. Hume'a göre, gereklilik ve nedensellik fikrimiz doğadaki benzer nesnelerin daima bir araya getirildiği zihnimizle ilişkilidir. Zihnimizde bir görünüşten diğerini çıkarsama alışkanlığı sebebiyle oluşan tekbiçimlilik düşüncesinden doğmaktadır (Hume, 2007: 59-60). Böylece Hume'un düşüncesinde hem bilginin insan deneyimleri ile ortaya çıktığı hem de bu bilginin zincirleme bir belirlenimciliğin içinde olmadığı ifade edilmektedir. Bu bakımdan da kökene ilişkin sorgulama yapılırken mevcut bilginin eskiden beri süregelen bilgiden türemediği iddia edilmiş olunmaktadır. Çünkü arada birbirini gerektiren ve neden olan bir bilgi oluşumu bulunmamaktadır. Öyleyse nesneler ve olaylar arasında nedensel bağ olmadığı gibi bilginin de nedensel bir bağla devam etmeyeceği öne sürülebilmektedir.

Ancak bilgi ile eylem arasında kurulan ilgi her ne kadar Hume'un düşüncesinden beslenmiş olsa da temellerini Herakleitos'a kadar dayandırır. Herakleitos'un değişme ve akışkanlık hakkındaki görüşleri önemli bir çıkış kaynağını oluşturur. Nietzsche, Deleuze ve Guattari, Derrida ve Foucault geleneksel düşünce içinde anlamın, sabitlik ve bir yapı temelinde varlık ile birlikte düşünüldüğünü öne sürmüşlerdir. Derrida'nın ifadesinde bu bakış açısı mevcudiyet metafiziği adıyla daha açı olarak belirtilmiştir. Bu mevcudiyet, onlar açısından değişimin ve hareketin ve eylemin ve özgürlüğün önündeki engel olmaktadır. Bir sabit anlamın mevcudiyeti, değişimin de o anlamın tamamlanması ile açıklanmaktadır. Anlamın kendisi bir sabit varlık haline gelerek yapıya dönüşmekte ve böylece eyleme, oluşa ve özgür kalmaya üstünlük kurmaktadır.

Nietzsche için var olan bir şey daima daha üstün bir güce ihtiyaç duymaktadır. Bu ihtiyaç aynı zamanda boyun eğdirmenin de ara- 
cılmaktadır. Oysa, ona göre, eylem her şeydir ve aynı zamanda boyun eğdirmenin de karşısında duruştur. Deleuze da Nietzsche gibi her şeyin kalıcı olmayan şekilde akışkan olduğunu söyler. Akışkanlık sürekli bir değişim ve oluş anlamına gelmektedir.

Ancak her şeyin akışkan olduğunu söylemek bizzat bu ifadenin de akışkan olmasını gerektirdiği için burada doğru olarak kabul edilebilecek ifade ancak bazı şeylerin akışkan ve bazı şeylerin de değişmez olduğudur. Aksi halde söz kendi çelişkisini içinde barindıracaktır.

Derrida' nın yaklaşımı geçmişte sıkça kullanılan neden sorusunu ortadan kaldırmaktadır. Bizzat determinist bir açıklama ortadan kalktığı için hareketin nedeni de sorgulanmamaktadır. Çünkü başlangıcı ya da sonu olmadan her şeyin hareket olduğu bir durumda neden sorusunun sorulması dahi tuhaf olacaktır. Hiçbir şey sabit olarak var olmadığına göre neden ya da etki ya da sorumluluk dahi olmamaktadır.

Derrida' nın düşüncesinde arke-yazı ile bir varlığın ya da yapının mevcudiyetinin sorgulanması ortaya çıkmaktadır. Ancak her ne kadar arke-yazı, farklılığın hareketi olarak ifade edilse de onun indirgenemez olması ve herhangi bir dil sistemi içinde bulunamayışı bizzat metafizik bir söylemi ortaya koymaktadır. Bu durumda arke-yazının metafizik hali ile mevcudiyet metafiziğinin hali birbirinden farklılaşmaktadır. Arke-yazı mevcut olmayan bir haldeki metafiziğe karşılık gelir. Burada hareket ve farklılık ise bizzat metafiziğin hem oluştuğu hem değiştiği şey haline gelir. Oysa sürekli metafizik bir değişim ve farklılık insanların birbirlerini anlamamasını gerektirir. Derrida'nın differance' 1 tarif edebilmesi dahi bir sabit anlam zeminine ihtiyaç duymaktadır. Öte yandan tüm eski kaynakların deşifre edilebiliyor olması da anlamın kendi içinde hem sabit kalabildiğini hem de değişebildiğini göstermektedir. Zira deşifre sonucunda anlamın tam olarak, bütün sınırlarıyla kavranabildiğini söylemek de güçtür.

Foucault'un yaklaşımı da bu bağlamda artık çağımızda hemen herkesin aşina olduğu bir düşünceyi ortaya koymaktadır. Pozitivist yönelimli, ilerlemeci tarih anlayışı yerine kesintilerin olduğu, 
hatta birbirini takip etmeyen tarihsel olayların vuku bulduğu tezi benimsenmektedir. Böyle bir tarih anlayışı doğal olarak şartlara ve bağlamına göre olayların yorumlanmasını gerekli kılmaktadır. Bu durumda da tıpkı diğer postyapısalcı düşünürlerin öne sürdüğü gibi herhangi bir köke, sabit bir inanışa, değişmeyen bir varlık biçimine ihtiyaç kalmamaktadır. Zaten süreksizlik daha önce kabul edilen düşüncenin geçerliliğini yitirdiği iddiasını öne sürmektir.

Foucalt'nun süreksizlik için verdiği örneklerden daha fazlası sürekliliğin mevcut olduğunu iddia etmek için de öne sürülebilir. Ancak burada Foucalt'nun kendi yaklaşımının izlerini Althusser, Nietzsche, Spinoza, Herakleitos ve Sofist düşüncesinde bulmak yeterince açıklayıcıdır. Bu haliyle tarihin süreksizliği düşüncesi seçilmiş eylem, hareket ya da oluşlardan türetilmiş bir önermeden ibarettir. Hareketten ve değişimden yola çıkmaktadır ama hareket ve değişimi değişmez doğru olarak kabul etmektedir. Oysa Foucault'nun kendinden önce yaşamış olan düşünürlerden faydalanması hem değişen hem de sabit kalan bir tartışmayı gösterir. İkisinin bir aradalığını ortaya koyar. 
Ömer Say

\section{Kaynakça}

Buachanan, I. (2008), Deleuze ve Guattari'nin Anti-Ödipus'u, (F. Ege, \& H. Erdoğan, Çev.) Ankara: Bilim ve Sosyalizm Yayınlari.

Deleuze, G. (2015), Anlamın Mantığı, (H. Yücefer, Çev.) İstanbul: Norgunk Yayıncilık.

Deleuze, G. (2002), Nietzsche and Philosophy, (H. Tomlinson, Trans.) London: Continuum.

Deleuze, G., \& Guattari, F. (2014a), Anti-Ödipus, Kapitalizm ve Şizofreni 1, (F. Ege, H. Erdoğan \& M. Yiğitalp, Çev.) Ankara: Bilim ve Sosyalizm Yayınları.

Deleuze, G., \& Guattari, F. (2014b), A Thousand Plateaus Capitalism And Schizophrenia, (B. Massumi, Trans.) London: Bloomsbury Academic.

Derrida, J. (2005), Writing and Difference, (A. Bass, Trans.) London: Routledge Classics.

Derrida, J. (1997), Of Grammatology, (G. C. Spivak, Trans.) London: The Johns Hopkins University Press.

Derrida, J. (1982), Positions, (A. Bass, Trans.) Chicago: The University of Chicago Press.

Derrida, J. (1981), Dissemination, (B. Jhonson Trans.) London: The Athlone Press.

Derrida, J. (1973), Speech and Phenomena And Other Essays on Husserls Theory of Signs, (B. Allison, Trans.) Evanston: Northwestern University Press.

Foucault, M. (1996), "Language, Counter-Memory, Practice” D. F. Bouchard içinde Nietzsche, Geneology History, (D. F. Bouchard \& S. Simon, Trans.), (p.139-164), New York: Cornell Paperbacks.

Foucault, M. (1972), The Archaeology Of Knowledge And The Discourse On Language, (A. M. S. Smith, Trans.) New York: Pantheon Books.

Hume, D. (2007), An Enquiry Concerning Human Understanding, (P. Millican, Ed.) New York: Oxford University Press. 
Kılıç, S. (2013), Deleuze-Guattari: Şizoanaliz Yaratıcı Bir Fark ve Arzu Ontolojisi, Ankara: Sentez Yayıncilık.

Nietzsche, F. (2008), On the Genealogy of Moralit, (C. Diethe, Trans.) (K. Ansell-Pearson, Ed.) Cambridge: Cambridge University Press.

Nietzsche, F. (2004), Putların Alacakaranlığı, (Z. Eyuboğlu, Çev.) İstanbul: Say Yayınları.

Russel, B. (1983), Batı Felsefesi Tarihi, (M. Sencer, Çev.) İstanbul: Say Yayınları.

Say, Ö. (2010), Toplum Düşüncesinde Görecilik, İstanbul: Kaknüs Yayınları. 